\title{
The Review of Lolitics
}

Published Quarterly by the University of Notre Dame, Notre Dame, Indiana.

\section{Some Reflections on the War}

The Review of Politics does not propose to compete with the papers or broadcasting systems in presenting today's news. Nor has it the aim of evaluating events which are known mostly in their superficial aspects. But this renunciation of propaganda and of all service to the swiftly-passing moment is connected, at the same time, with a positive obligation. We should attempt to understand the deeper significance of the events. World history marches on behind the explosion of bombs, the sinking of ships, the maneuvers and advances of armies, and the noise of propaganda machines. Even though one does not care to explain its mysteries and to know the laws of its evolution, one is obliged to look beyond the present. This signifies a judgment on those ideologies which do not know nuances, only "black and white," adapted to the needs of mass propaganda. We shall attempt to fulfill this task in offering some reflections on the war. We shall indicate questions which cannot be answered today, but which must be answered if we will fully comprehend our times. We shall discuss connections of facts and ideas which can aid in estimating the importance of events. We shall review books expressing some aspects of the mentality of our epoch. We hope to do it sine ira et studio, without allowing prejudices to overcome the faculty of judgment, though not as uninterested spectators (or perhaps spectators only interested in the sensational side of the events). World history, the voice of which speaks in the most audible way through the World War, is not merely a play. It deals with the destiny of man, who really lives, acts, suffers and dies. 
Everyone knows how the new World War began. At least, some important documents are known. One can read the English White Papers in the New York Times, and we believe the German version of the events will soon be available in an English translation. The maneuvers of the last months brought some surprises. The conclusion and publication of the German-Russian non-aggression treaty has provoked the explosion of the crisis smouldering since the German occupation of Prague. The Soviet Union does not fight against Hitler's Third Reich. The attitudes of Stalin's empire and Mussolini's Italy are the big question-marks of the war. Perhaps we shall know the answers soon. Perhaps we shall have to wait for them. Does Italy, by its neutrality, begin to draw away from Germany, or is this move only a tactical one in agreement with Hitler? Italy, through its military alliance with the Third Reich, had been apparently obliged to enter war at once. Why was Chamberlain so surprised at the treaty concluded between Germany and the Soviet Union? Had he taken Stalin's speech of last spring, which claimed that there are no insurmountable conflicts between Germany and the Soviet Union, too lightly, and the Nazi challenges to the Soviet Union too seriously? Why has Colonel Beck rejected the German proposals, apparently made this spring, to organize a drive against the Soviet Union? These are only a few of the questions which must be answered if one is to discuss the diplomatic history of the origins of the war, and these questions cannot be answered today. We do not yet possess enough facts.

There are other questions touching the future which, we are afraid, cannot be sastisfactorily answered, even by those for whom these secret archives contain no mysteries. For instance, how long will the German-Russian co-operation last and what form will it assume? Who will finally double-cross whom?

However, one can make some general remarks about the situation immediately preceding and following the outbreak of the second World War. It differed greatly from the situation of 1914. Surely there was also, in 1914, a universal fear of war. But this fear of war was 
not so deeply rooted as that of our day. Despite many discussions, it had more or less the character of a newspaper affair, and was not of vital concern to all. Important crises had been solved by Great Powers without that loss of prestige by one side which occurred in Munich in 1938. And, after all, there had not been the experience of the World War.

The much more vital and extensive fear of war before September, 1939, compelled every country to have much more concern for public opinion, perhaps more exactly for the feelings of the masses, not only for those at home, but also for those abroad. The memories of 191418 were frightening, and one had to consider the strength of pacifistic attitudes. In Germany one was not willing to repeat the "naiveté," as one said, of Chancellor Bethman-Hollweg, who had confessed German guilt toward Belgium and had sent out superfluous declarations of war. And in England as well as in France one was anxious to obtain, likewise, notarized legal proof of German war guilt.

Everything was much better organized-not only armed forces, but also war economics and propaganda. But these improved preparations for war had produced a rather depressed mood. There was no enthusiastic hope of victory, no jubilation. The feeling of the unavoidable necessity of fulfilling a duty, the sobriety of attentive handling of machines, seemed to have been dominant during the crisis and the beginning of the War. The organization of the masses does not know spontaneous mass-enthusiasm. Everything must be moved, organized, directed. Will this mood be a lasting one, or will rage and hate develop and increase with the help of the propaganda machines and events of the War?

\section{II}

It is a strange coincidence that, this year, just a few months before the war, Immanuel Kant's Perpetual Peace ${ }^{1}$ was published again in this country. It is useful, for an understanding of war in our time, to refer to this old pamphlet.

1 Columbia University Press, New York, 1939, ix, 67 pp., \$1.00. The lext of this edition follows that of the first English edition published in London in 1796. 
The philosopher of Königsberg had not believed that perpetual peace would be easily or soon realized. It was, for him, rather an idea destined to regulate actions of states. Many statements have to be explained by the particular situation in Kant's time, dominated as it was by an opposition to the egoistic and artificial policy of absolutist princes. Kant is, for example, of the opinion that commerce and moneyed interests will work for peace. P. J. Proudhon, in his book La Guerre et la Paix first published in 1861, is surely more correct in stressing the economic aspect of war which is directed toward spoils and booty. And there is Kant's belief that representative bodies would be less enthusiastic for war than absolute princes; for the citizens themselves must pay for war. Kant's whole argument is not "idealistic," dominated by a too-powerful belief in human goodness. His perpetual peace is a reasonable harmony more advantageous than the insecurity of war. It was possible to realize, within the limits of the state, the legal order with its rule of law, excluding the war of all against all. The same development will take place also in the international system of states, perhaps, step by step, very slowly and only in certain approximation with the regulative idea of perpetual peace. The realization of public international law excludes war, Kant writes (p. 21) ". . . however, from her highest tribunal of moral legislation, reason without exception condemns war as a means to right, and makes a state of peace an absolute duty; and since this peace cannot be effected or be guaranteed without a compact among nations, they must form an alliance of a peculiar kind, which might be called a pacific alliance (foedus pacificum) different from a treaty of peace (pactum pacis) inasmuch as it would forever terminate all wars, whereas the latter only finishes one. This alliance does not tend to any dominion over a state, but solely to the certain maintenance of the liberty of each particular state partaking of this association, without its being therefore obliged to submit, like men in a state of nature, to the legal constraint of public force." The idea of collective security is formulated here.

Kant's views on perpetual peace were harshly criticized by another famous German philosopher. Hegel rejected the idea of perpetual peace. According to him the political world would be corrupted if 
this peace would be realized. The strong state, the mouthpiece of the movements of world history, decides exclusively concerning its relations with other states. Its right of existence is the right. There is no judge above the states. A world history remaining stationary is, for Hegel, an absurdity, and that is the substance of Kant's Perpetual Peace. War manifests, for Hegel, which state has the movement of world history on its side (naturally not every war, not armed conflict which has no general importance).

But it is best to let Hegel speak for himself. In the note to paragraph 303 and 334 of his Philosophy of Right, ${ }^{2}$ he emphasizes the conflict between sovereignty and the idea of perpetual peace. "There is no judge over states, at most only a referee or mediator, and even the mediatorial function is only an accidental thing, being due to particular wills." (That is, the mediator or referee can only exercise his function if he is accepted by the particular sovereign state.) "Kant's idea was that eternal peace should be secured by an alliance of states. This alliance should settle every dispute, make impossible the resort to arms for a decision, and be recognized by every state. This idea assumes that states are in accord, an agreement which, strengthened though it might be by moral, religious, and other considerations, nevertheless always rested on the private ${ }^{3}$ sovereign will, and was therefore liable to be disturbed by the elements of contingency. Therefore, when the particular wills of states can come to no agreement, the controversy can be settled only by war. Owing to the wide field and the varied relations of the citizens of different states to one another, injuries occur easily and frequently. What of these injuries is to be viewed as a specific breach of a treaty or as a violation of formal recognition and honor remains from the nature of the case indefinite. A state may introduce its infinitude and honor into every one of its separate compartments." Thus, the state alone decides when its honor and vital interest are violated, and there war begins. In the addition to paragraph 324 also, he contends energetically against Kant. “. . . Ever-

2 We quote Hegel's Philosophy of Right, translated by S. W. Dyde, London, 1896, p. 338.

3 We do not know why the word besondere is not translated here by the word particular. Hegel has the particular sovereign will of states in mind. As a German text, the edition of Lasson, Leipzig, 1911, was used. 
lasting peace is frequently demanded as the ideal towards which mankind must move. Hence, Kant proposed an alliance of princes, which should settle the controversies of states. . . But the state is individual and in individuality negation is essentially implied. Although a number of states may make themselves into a family, the union, because it is an individuality, must create an opposition, and so beget an enemy. As a result of war peoples are strengthened, nations which are involved in civil quarrels winning repose at home by means of war abroad. It is true that war occasions insecurity of possessions, but this real insecurity is simply a necessary commotion."

The conflicting views of the two German philosophers anticipated the conflict of our time. Hegel was justified by current events after the first World War, (which naturally does not prove that he was right. He characterizes an existing trend.) Collective security did not work. For security in general was thought, and not alone by Germans, to be a guarantee of insecurity for those who were the victims of Versailles, St. Germain, etc. It was not possible to separate peace and maintenance of the status quo. The idea of a general security permitting only slow, peaceful changes, had not prevailed against the idea of the vital rights of existence, etc. It became thinner and thinner, until it appeared to be only a fear of making decisions and an abandonment of weaker parties. But even this had not attained its end. The catastrophe of war occurred, for no one was there to decide about vital rights. Who could judge if Germany's right demanded in 1939 concessions from Poland which were renounced in 1934, at least until 1944; or if it was the duty of the Poles, as it seemed to be the duty of the Czechs in 1938, to rescue world peace by sacrifice, if only for a brief time. "Quis iudicabit?" This question could not be solved by any judge, and the war began.

\section{III}

What will be the character of this war? For Hegel the war is, despite all his enthusiasm, a limited affair between states and not directed against the family and private citizens. This situation no 
longer exists ${ }^{4}$ in the twentieth century. The war assumes, at the same time, a military, revolutionary and economic character. The war is no longer a cabinet war, conducted with the help of nationalistic passions, for the possession of a specific territory. The war of today is like the wars of the French Revolution-a war of highest national tension. But this tension is of much greater pressure, because we possess, today, quite other technical and economic potentialities. The knowledge of these potentialities produces the rise of the idea that war and most complete planning are intimately connected. The plan is totalitarian, embracing everything that is useful for the conflict. Even the absolute war of Clausewitz, ${ }^{5}$ the aim of which is destruction of the enemy by the use of all forces, is harmless in comparison, for it is conducted in the service of a specific order, whereas, now, the question of the order is no longer asked, and the war becomes an end in itself. Even before the publication of General Ludendorff's study on totalitarian warfare, the German writer, Ernst Jünger, gave a classical description of this character. ${ }^{6}$ Of special importance is his view that technical development is a new means of stressing and expressing the non-rational elementary character of war. The techniques do not decrease, but increase the intensity of warfare. Hegel believed in reason. This belief has vanished; there are only elementary forces and power expressed by war. Everything is put into use for them, beginning with religion and philosophy, and ending with diet. The most complete rationalization is in the service of the most complete irrationalism. The distinction between peace and war is abolished for the state preparing totalitarian

4 How this situation changed during the first World War is universally known. For the striking case of enemy property in war-time one may refer to the article of $R$. Littauer in $W$ ar in Our Time, published by the Graduate Faculty of the New School for Social Research, W. W. Norton \& Co., New York, 1939, p. 278. Certain rules limiting warfare may be observed, but only for technical reasons. For instance, the distinction between uniformed military forces and the civil population is useful for military purposes, especially for the conqueror.

5 Compare Clausewitz, On War, English edition, Vol. 3, London, 1911, pp. 79 ff. Clausewitz knew, naturally, that absolute war was realized in the French Revolution, with its popular armies. We do not know if the criticism of Clausewitz by General Ludendorff, The Nation at $W$ ar, is justified on all points. It may be that Clausewitz did not deal enough with economic planning, but he knew exactly the importance of the national basis and popular enthusiasm for the absolute war.

$6 \mathrm{Cf}$. his article in the book Krieg und Krieger, Berlin, 1930, entitled "Die totale Mobilmachung" (Totalitarian Mobilization). Cf. also the article of Hans Barth in the July Review of Politics. 
warfare. The totalitarian character of the plan also embraces peacetime, which is seen only as a period of preparation for war. Totalitarian war is only possible if there are war economics dominating times of peace.

This conception of war could come into existence only in a world for which the appeal to reason against decision by force appears to be either meaningless or an instrument of deception. Therefore, the believers in this conception are able to develop a particular technique of intercourse with a surrounding world not yet understanding the character of totalitarian warfare. They can accept the pacifistic slogans of others and, at the same time, build up their power. The pacifistic slogans are, likewise, means of making the increase of armament invisible.

Hitler has applied these tactics in a most masterly way. Had he not the right to build up the German army because the others had not fulfilled the promise of a general disarmament? Why should he be prevented from using, on behalf of the German people, the right of national self-determination after the others had used it against the German people? These are only two examples.

Will these tactics also be applied in the future, during the war, though in a changed form? That means the totalitarian war has been announced so often in advance that it will not start at once with full speed, but will be realized only in stages of increasing intensity. Swift blows will be mixed with peaceful assertions. Poland is not yet defeated and France is spared. The generally expected air attacks against the cities do not occur for a long time. Will this war, therefore, which is accelerated step by step, be more terrifying, or will it be finished relatively soon because of the depressing fear for the future? Perhaps one speaks too much, today, about the long war, as one spoke too much in 1914 about the short war.

But, in any event, one must fear that the crisis which was manifested by the war, can no longer be prevented from growing. Perhaps the loss of substance of the old social forces has proceeded too far. We have too many negative slogans, and those apparently positive are only appeals to the discipline of external unity, blind confidence in those 
on command. But the belief is not there. Confidence in reason, which is inherited from the 18th century and exists today, though it has become utilitarian and is weakened by a relativistic skepticism, is opposed to political mass-religions. Enthusiasm is lacking. It must be artificially created. Chamberlain has to assert today what he has, until now, refused to believe: that the Fuehrer is a man of bad faith and the greatest impediment to peace. The German-Russian non-aggression treaty replaces the anti-Comintern pact and both treaties are signed by the same man-von Ribbentrop. That is perhaps the most spectacular feature of the crisis of today. Overheated statements and sudden moves are made to cover internal insecurity, and one lives in the shadow of the past. The old slogans about the fight for liberty and "keeping the world safe for peace" appear again. Hitler replaces William II and, on the other side, the Third Reich will avoid the faults committed twenty-five years ago. One claims that the German army is much better than that of 1914, and one organizes mass propaganda, believing that the first World War was lost because it was not employed then on the side of Germany. Surely there was cynicism existing in 1914 also, but it is today colder, more technical, and it calculates not with a limited social circle but with mass feeling. The cynicism is fed by the knowledge that war and revolution are connected. ${ }^{7}$ This knowledge has an ancient history. Instigation of revolts, the subsidizing of one party in the camp of the enemy, are old war tactics. One knows the promises of the armies of the French Revolution, and even Bismarck was willing to use, if necessary, nationalistic movements against Austria. Socialists liked to announce that the war would be only a preparatory step towards their revolution.

But all this was, during the first war, effective only under the democratic cloak. One attempted to organize it as a fight for democracy and self-determination. The German slogans could not work against this democratic enthusiasm. Central Europe and authoritarian states had a too localized and complicated meaning. Will this situation change today?

7 Totalitarian war is aimed not only at the destruction of armies, but is a test of the stability of the entire social, political and economic system. The revolution is nothing more than a proof that this system could not bear the tension and thus explodes. 
The slogan of the proletarian nations was often used in Europe, but, until now, not very seriously-and was, more or less, a journalistic or literary affair. It may be that the slogans opposing international capitalism to nation will exercise the same dissolving force in the second World War as did the democratic slogans in the first. In the war with a powerful totalitarian state, one has to accept its example. That is, one has to become oneself totalitarian. This point was often emphasized by those who were willing to avoid the war at almost any cost. Will there be any success in re-shaping the totalitarian state? Or will totalitarian society assume a permanent character? Will it be possible to abolish the regulation of economics, the militarization of all life, or will the vision of Jacob Burckhardt, the wise man of Basle, be realized everywhere? In a letter of 1872 , Burckhardt writes: "Most strangely will labor fare; I have a notion which for the time being sounds like foolishness and yet will not leave me; the military state must become a large-scale manufacturer. Those masses of people in the large factories cannot forever be left to their distress and to their raging desires; a certain and regulated amount of misery with promotion and in uniform, daily started and finished with drums rolling, that is what ought to follow logically. .."8

Loss of substantial character to be observed in leading circles has made the war possible. All ideas threatened to become pure thetoric. Many things could be maintained for a long time because they were not seriously attacked. But what can withstand the merciless ordeal of war? The attempt has been made to fill in the gaps produced by the loss of the old religion through substitutes-by enlightenment of reason, by religion of progress, by deification of the masses, either as a productive proletariat or as a racial and national unity symbolized in the Leader. Nothing was of help. The void remained. Will it be possible always to maintain a numbness of the senses, either by opiates or by terrorism? Are we entering upon a period of wars or upon a period of undignified quiet (perhaps after some convulsions) in which corrupt characters dominate, or will the crisis of our time be

8 Quoted from Alfred Vagts' History of Militarism, W. W. Norton Co., New York, 1937, p. 464. 
a catastrophe of purification, manifesting the real depths of existence to the rhetoricians who live by a heritage in which they themselves no longer believe? Will it replace the cynicism of mass propaganda by the needs of true faith? Will it prove the meaninglessness of limited egoisms and of tribal religions?

\section{IV}

There were recently published in the United States two books illustrating the situation today. We speak of Hitler's Mein Kampf ${ }^{9}$ and Rauschning's Revolution of Nihilism. ${ }^{10}$ Today we shall devote only a few lines to these books. We hope to have an opportunity to discuss them later from another point of view.

Perhaps some will believe it is meaningless, today, to deal with Hitler's book: One should look upon it only as a historical document. Hitler develops, in his work, the project of an alliance with England, whereas he is much aroused against France. Today he wages war against England, accompanied by the sharpest propaganda. In contrast, France is spared, and characterized as a victim of English seduction. Hitler is opposed, in his book, to all collaboration with the Soviet Union, and sketches projects for obtaining Russian territory; and in 1939 he has concluded a German-Russian non-aggression pact. Rauschning, too, the now disillusioned former Nazi, emphasizes in his book, written before the last events, how wrong it is to believe that Hitler's book contains his program of foreign policy.

But one still has to read Hitler's book, though not in order to study therein the developed program of international relations as a key to actual events. The importance of this book lies in its manifestation of Hitler's fundamental attitude. Hitler has a fixed aimGermany's world power. This world influence can be created only with the help of a strong leadership. But this leadership cannot dic-

9 We recommend the edition published by Reynal \& Hitcheock, New York. The annotations are very useful, though one might have wished they had a more systematic character and had been more clearly connected with the text. One cannot understand why the index was omitted.

10 Rauschning was President of the Danzig Socialistic Senate from 1933-34. His work has just been published by the Alliance Book Company, New York, $\$ 3.00$. 
tate from above; it must dominate the souls of the masses. Organization and mass-propaganda are necessarily connected with it. We advise everyone to read the chapters dealing with propaganda (Ch. VI of Vol. 1, Ch. XI of Vol. 2). The propaganda must be clearly directed toward a particular goal, and must always justify its own ends, always villifying the adversary, and always directed, not toward the intellectuals, but toward the most primitive of the masses, constantly repeating the same slogans. The organization, as well as the racial worldoutlook, is used to secure for this propaganda the character of a monopoly.

Of importance also is the understanding of Hitler's hierarchy of peoples and races. Not all peoples and races are equal; there are races of people destined to rule and to be ruled. If one comprehends this attitude, one does not misunderstand Hitler's position as a fighter for the principle of national self-determination. Surely, he will not make Poles into Germans, as he stated in 1933, but he will dominate them.

Rauschning has the merit of pointing out the revolutionary character of National Socialism, which one can observe in Hitler's Mein Kampf despite all cautious disguise. National Socialism, for Rauschning, is not a movement primarily directed towards the restoration of Germany, which was so badly hurt by the treaty of Versailles. National Socialism is, for him, a movement oriented towards a limitless expansion. It is dominated by an elite which despises the masses and at the same time knows how to master them with the help of psychological means. This elite takes for granted the corruption of the dominant social classes throughout the world. These circles take nothing seriously. Not only military power but internal dissolution is used as an instrument. Rauschning illustrates his view by comparing National Socialist domestic and foreign policies. The so-called conservative forces opposing the Weimar democracy are used as allies, and, in the domestic policy, anti-Communism and the apparent fight for the right of national self-determination are utilized.

Rauschning opposes the revolution of national Socialistic nihilism to national conservatism with limited aims which would be interested 
in real order and not in exploitation of Eastern Europe, and which would not deify the power but would recognize the religious foundations and moral obligations of authority. Even though one does not know if the practical proposals of the book are of the same value as its analysis of the National Socialist nihilism, one has to state that the latest events have proved how correct Rauschning was. The change of the National Socialist attitude toward Stalin's Soviet Union has again illustrated that the National Socialistic ideologies are used as justifications for the exigencies of power. The anti-Communistic slogan has done its work. The power was now strong enough to abandon it, as a collaboration with the Soviet Union appeared to be useful, and it was abandoned, at least for the time being.

It may be that Hitler's Mein Kampf stresses more strongly the ideological aspect of Nazism; that was, until now, necessary if only for propaganda purposes. Today the doctrinal character which was so impressive during the times of preparation and rise is retreating; the power can speak directly. The tanks are launched; the armies are on the march-but on the march where? Will they soon reach their limits, or has the second step of world revolution started? The first was prepared in 1914 by the outbreak of the first World War, and has found its organization in Bolshevism since 1917. Will the second war have a function similar to the first? The dice are cast, but we do not yet comprehend the meaning of their numbers. 